\section{Storying stories}

Ad A. Kaptein, ${ }^{1}$ Antonia C. Lyons, ${ }^{2}$
A. Scott Pearson, ${ }^{3}$ Sjaak van der Geest, ${ }^{4}$
Joost Haan, ${ }^{5}$ Frans Meulenberg, ${ }^{6}$
Joshua M. Smyth
7
'Section Medical Psychology, Leiden
University Medical Center, Leiden, the
Netherlands; ${ }^{2}$ School of Psychology,
Massey University, Wellington, New
Zealand; ${ }^{3}$ Department of Surgery,
Vanderbilt University Medical Center,
Nashville TN, USA; ${ }^{4}$ Department of
Sociology and Medical Anthropology,
University of Amsterdam, Amsterdam, the
Netherlands; ${ }^{5}$ Department of Neurology,
Leiden University Medical Center, Leiden,
and Rijnland Hospital, Leiderdorp, the
Netherlands; ${ }^{6}$ Department of Medical
Ethics and Philosophy of Medicine,
Erasmus University Medical Center,
Rotterdam, the Netherlands;
${ }^{7}$ Departments of Biobehavioral Health and
Medicine, Pennsylvania State University,
University Park, PA, USA

\section{Abstract}

In many countries courses on Literature and Medicine (LitMed) are part of the medical curriculum, to develop and teach knowledge and skills in the area of Medical Humanities. We describe a LitMed course designed to encourage medical students at a university medical center to incorporate the biopsychosocial model into their clinical skills. A LitMed course for medical students is described and contextualized within the field of medical humanities with a focus on biopsychosocial responses to illness. The components of the course are presented, along with details of specific relevant novels employed, other study materials, and assignment examples. Preliminary evidence for positive course outcomes included students publishing peer reviewed papers, and enthusiastic faculty response. The course also led to renewed initiatives to incorporate LitMed in the medical curriculum. Suggestions for future teaching activities in this area are provided. Teaching a LitMed course is feasible, strengthens the adoption of a biopsychosocial approach in medical students, and is evaluated positively by students and staff from medical schools.

\section{Introduction}

The voice of the patient, the narrative of the patient, his/her story, has become more impor- tant over time, as the patient has become increasingly involved in the medical care s/he receives and in the self-management required for most illnesses. ${ }^{1-3}$

Medical students usually receive some (albeit often modest) degree of training in medical psychology. Ideally, this should assist their understanding of the importance and relevance of self-management and patients' perceptions of their illness, treatment and own accounts of their medical condition (narratives, stories) in modern medical care. ${ }^{4}$ In a guiding document defining content and end-terms of the curriculum for medical students, emphasis is placed on strengthening the degree of patient involvement with medical care. ${ }^{5}$ Coping, self-management, illness perceptions, quality of life and disease management are relatively recent developments in medical care. Of note, they are associated with improvements in outcomes of medical care for patients with chronic medical conditions ${ }^{6,7}$ Studying the patient's story - the narrative - fits in with disease-management: the patient's story is the starting point for a cascade that leads from medical consultation, receiving encouragement to self-manage the condition as much as possible, to creating a more or less coherent story of what the illness entails for the patient in daily life. ${ }^{8}$

Medical Humanities provides the context for Literature \& Medicine. Recently, Brody defined this field: the medical humanities use the methods and concepts of one or more of the humanities disciplines, teach students critical reflection aimed toward a more humane practice, and are by nature interdisciplinary and collaborative. ${ }^{9}$ Within the Medical Humanities, Literature and Medicine has been defined as researching and understanding the interfaces between literary and medical knowledge. Literary and cultural texts are used to examine concerns related to illness, trauma, the body, and other medical issues (from the mission statement of the journal Literature and Medicine).

Empirical research lends support for integrating Medical Humanities in the medical curriculum, and Medical Humanities education is a burgeoning topic in medical journals (this journal devotes attention to this issue as well, e.g., Bell et al. $)^{10}$ With this said, research on the effectiveness of Medical Humanities on various aspects of behavior of medical students and physicians is still quite scarce - although the emerging evidence is promising. Khorana and colleagues present preliminary data on how reading novels and poems can enhance oncology training. ${ }^{11}$ Naghshineh and colleagues demonstrated how teaching medical students to look at and describe the skins of naked bodies on paintings led them to be better observers of real patients, compared to a control group who did not receive training. ${ }^{12}$ Ousager and Johannessen review the literature on humanities in the undergraduate medical education
Correspondence: Ad A. Kaptein, Leiden University Medical Center (LUMC), P0 Box 9600, 2300 RC Leiden, The Netherlands.

Tel. +31.71.5262905 - Fax: +31.71.5248123

E-mail a.a.kaptein@lumc.nl

Key words: Literature \& Medicine, Medical Humanities, medical students, biopsychosocial medicine, novels.

Conflict of interests: the authors report no conflict of interests.

Received for publication: 12 December 2011.

Revision received: 9 July 2012.

Accepted for publication: 16 July 2012 .

This work is licensed under a Creative Commons Attribution NonCommercial 3.0 License (CC BYNC 3.0).

(C) Copyright A.A. Kaptein et al., 2012

Licensee PAGEPress srl, Italy

Medical Education Development 2012; 2:e7 doi:10.4081/med.2012.e7

and conclude that some evidence for positive effects is available but that much more research is necessary. ${ }^{13}$ Perry and colleagues review arts-based interventions in medical education and similarly conclude that much more research is required..$^{14}$ In this context, the aim of our paper is to describe and evaluate a course on Literature \& Medicine for medical students, and suggest avenues for further development of this area.

\section{Innovation}

The Honours Class Literature \& Medicine (LitMed) was held in 11 three hour sessions, over a six-month period in 2010 . Table 1 provides an outline of the course content and material employed.,15,16 Inspired by descriptions of other experiments in teaching Literature \& Medicine, ${ }^{17}$ the following components of the Honours Class were part of the structure of the Class:

i. bring a novel or poem from one's own bookcase in the LitMed category to the Class

ii. write about one's own illness experience

iii. read patients' narratives, and define narrative type, and type of expressive emotions

iv. find and read a novel on an illness with a patient's narrative in the novel

v. interview a patient with an illness as described in that novel

vi. study and summarize the scientific literature on how patients with the chosen illness make sense of their illness

vii. write an essay on the novel, the scientific literature on biopsychosocial aspects of the ill- 
ness, and the narrative of the interviewed patient.

For each class session, two students worked collaboratively with the teacher in preparing that session's content and structure. During the class, the book Stories of sickness by Brody was used as a guideline (Table 1). ${ }^{8}$

The extraordinary range of topic material in LitMed raises pedagogic challenges. To address this, at least in part, rather than a single lecturer for the entire course, twelve teachers from various areas of specialty participated. Usually one or two novels were used as illustrations of the session's topic (Table 1). All students read the excerpts or the novel(s) before the session, with a chapter from the core book by Brody. In some sessions movies were used as illustrations (The singing detective, Potter, psoriasis; The Metamorphosis, Kafka, social isolation, stigma), whereas in other sessions music was employed (Marais on a lithotomy; Rossini on asthma; Manic Street Preachers on anorexia nervosa). In the session on gynecological cancer, the two teachers, both MDs, showed a video registration of surgery of the womb due to cervix carcinoma, together with an interview on videotape with the patient, a few months after the operation.

\section{Evaluation}

The themes of the 11 sessions together with the novels that were discussed and the chapters from Brody's book that were studied as background to the sessions' themes are also presented in Table 1. The first session of the Class was devoted to how material on LitMed is pub- lished both in journals devoted specifically to this topic (i.e. Journal of Medical Humanities, Literature \& Medicine, and Medical Humanities) as well as in major medical journals which have regular sections on Medical Humanities/ LitMed. Throughout the duration of the course, students were taught about core types of patient narratives as identified by Frank, namely the restitution, the chaos, and the quest narratives. ${ }^{4}$ As the capstone for the course, the
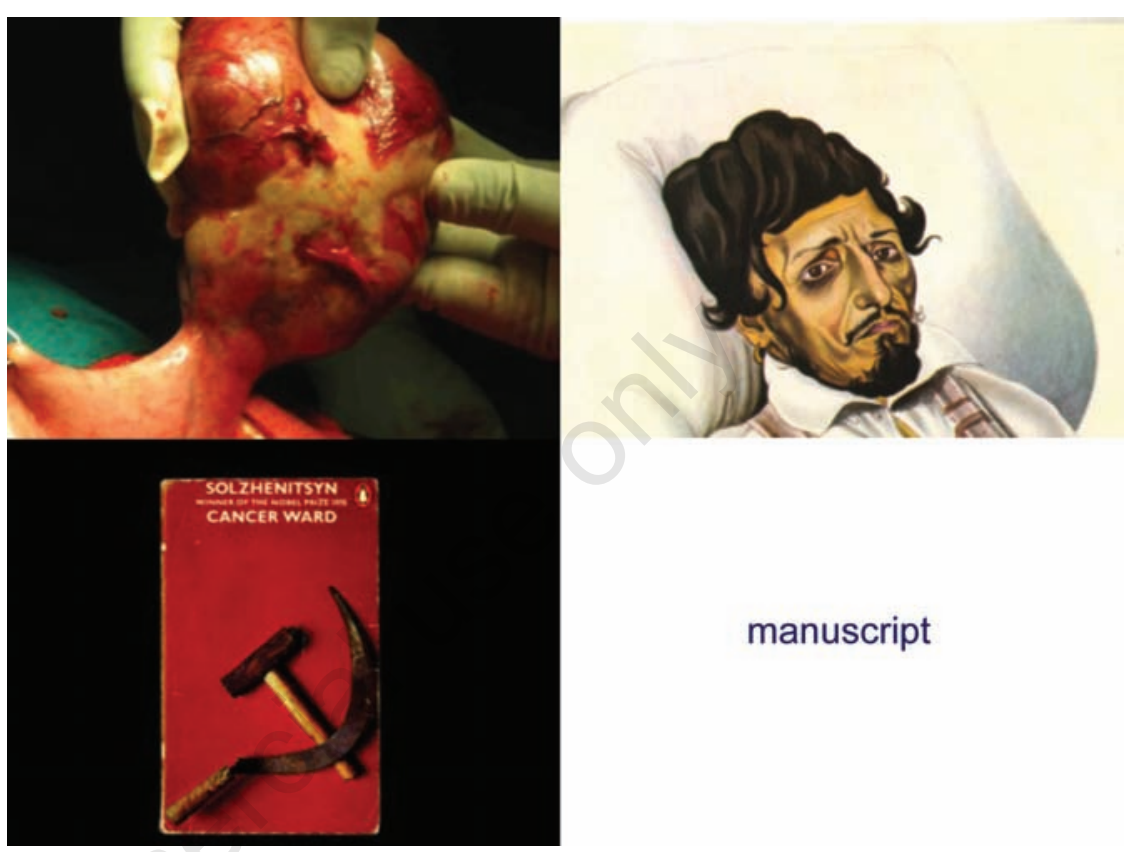

manuscript

Figure 1. The combination of biomedical knowledge (above left), patient's experience (above right), and a novel on the illness depicted (here: gastric cancer) (below, left) combines into a manuscript - didactical structure used in the Honours Class.

Table 1. Description of Honours Class course outline, topics, materials.

$\begin{array}{lll}\text { Session topic } & \text { Materials employed } & \text { Chapter from Brody's } \\ & \text { Book title (author) } & \text { Stories of Sickness }\end{array}$

Introduction

Biomedical vs. biopsychosocial model; Medical Humanities;

genres; narratives; effects of LitMed in medical practice; search strategies for publications and novels; the wounded story teller ${ }^{4}$

\begin{tabular}{|c|c|c|}
\hline Contagion & The Plague (Camus), Decamerone (Bocaccio) & Storytelling in medicine \\
\hline Migraine & The blindfold (Hustvedt), The horned man (Lasdun) & The nature and complexities of narrative \\
\hline Psychiatry & Take it or leave it: aspects of being ill (Rubinstein) & Dimensions of sickness \\
\hline $\begin{array}{l}\text { Medically unexplained } \\
\text { symptoms }\end{array}$ & A la recherche du temps perdu (Proust) & Sickness, life stories, and self-respect \\
\hline Expressive writing & Publications by Smyth & Types of stories about sickness \\
\hline $\begin{array}{l}\text { Students report on } \\
\text { progress of their reading } \\
\text { and writing in the context } \\
\text { of their assignment }\end{array}$ & All previously studied material in the course of the Class & Sick roles: practices and life plans \\
\hline Dermatology & $\begin{array}{l}\text { From the journal of a leper (Updike); } \\
\text { The hidden delight of psoriasis (Meulenberg) }\end{array}$ & How sickness alters experience \\
\hline $\begin{array}{l}\text { Medical might/medical } \\
\text { powerlessness }\end{array}$ & The Breath (Bernhard) & Stories of life with disability \\
\hline Gynecology & W;t (Edson); The Black Swan (Mann) & Maladaptive ways of being sick \\
\hline An author who is ill & The Bell Jar (Plath) & Conclusion: the patient-healer profession \\
\hline
\end{tabular}


Table 2. Authors, book titles and medical condition discussed - chosen by the students in the Honours Class; references to published papers by Honours Class students.

\begin{tabular}{lll} 
Author & Title of book & Medical condition \\
$\begin{array}{l}\text { Verghese } \\
\text { Tjechov }\end{array}$ & Cutting for Stone & Liver transplant \\
\hline Edson & The black monk ${ }^{18}$ & Psychosis \\
Krauss & W;t & Ovarian cancer \\
\hline Guibert & Man walks into a room & Glioma \\
Dumas & To the friend who did not save my life & HIV \\
\hline Pirandello & La Dame aux Camélias & Tuberculosis \\
Hesse & La Toccatina ${ }^{19}$ & Stroke \\
\hline Robinson & Sanatorium guests ${ }^{20}$ & Sciatica \\
McManus & Gilead & Heart failure \\
\hline DeQuincy & Going to the sun & Diabetes mellitus type 1 \\
Kafka & Diary of an English opium eater & Heroine addiction \\
\hline Barbellion & The hunger artist & Anorexia nervosa \\
\hline
\end{tabular}

the didactical structure that formed the basis for the essays. Table 2 lists the medical conditions, novels and authors that the students drew on in their essays as examples of the range of topics and issues that are raised in a course such as this..$^{18-21}$

Near the end of the Class, which lasted for six months, the students interviewed a patient with a (chronic) illness, usually in the patients' homes. Students reported to be particularly impressed by this interview. They were surprised about their skills in writing a paper - a task which is almost completely lacking in most medical curricula: ${ }^{17}$ students reported similar observations as quoted by Bolton: this is the first time I have been asked what I think. Perhaps the clearest objective outcome from the course was that every student wrote a publishable quality essay utilizing the skills and experiences learned in the class. As of this writing, four students (of 13) have had their papers published, ${ }^{18-21}$ while all other students have submitted their manuscripts to various journals. Most of the student participants (three-quarters) stated that the type and format of the course represented the best teaching experience that they had had within their medical training curriculum (and they were in their fourth year of study). Their active engagement, their involvement in different teaching sessions alongside various specialized instructors, and the rich literary material employed in the course were rated highly by the students. The instructors evaluated the collaborative preparation of their class sessions with students highly. They were impressed by the quality of the discussions during the class sessions. Course organizers attempted to generalize the positive experiences in the Honours Class to other components in other curriculum years.

\section{Conclusions}

Developing and teaching a course on Literature \& Medicine appears to be a feasible undertaking. Reading novels and patients accounts about illness, writing about experiencing disease, and listening to patients talking about their illness experiences are important components of such a course. Students come to understand and appreciate the biopsychosocial model of illness by combining biomedical, psychological and social aspects of disease and illness in the manuscripts they write about their observations. Our study offers opportunities for evaluating the effects of a Literature \& Medicine course, by examining views of patients, students and teachers. This is instrumental in ensuring a more structured position for Literature \& Medicine in medical schools.

\section{References}

1. Bodenheimer T, Lorig $\mathrm{K}$, Holman $\mathrm{H}$, et al. Patient self-management of chronic disease in primary care. JAMA 2002;288:246975 .

2. Lopez AD, Murray CCJL. The global burden of disease. Nature Med 1998;4:1241-3.

3. Bowen JL, Stevens DP, Sixta CS, et al. Developing measures of educational change for academic health care teams implementing the chronic care model in teaching practices. J Gen Inter Med 2010; 4:S586-92.

4. Frank AW. The wounded storyteller. Chicago, Il.: University of Chicago Press; 1995.

5. Frank JR, Jabbour M, et al. Report of the
CanMEDS Phase IV Working Groups. Ottawa: The Royal College of Physicians and Surgeons of Canada; 1995.

6. Newman S, Steed L, Mulligan K. Chronic physical illness: Self-management and behavioural interventions. Maidenhead: Open University Press McGraw Hill; 2009.

7. de Ridder D, Geenen R, Kuijer R, et al. Psychological adjustment to chronic disease. Lancet 2008;372:246-55.

8. Brody H. Stories of sickness. Oxford: Oxford University Press; 2003.

9. Brody H. Defining the medical humanities: three conceptions and three narratives. J Med Human 2011;32:1-7.

10. Bell SK, Krupat E, Fazio SB, et al. Writing community: a humanism curriculum with an academic lens. Med Educ Developm 2011;1:e4.

11. Khorana AA, Shayne M, Korones D. Can literature enhance oncology training? A pilot Humanities curriculum. J Clin Oncol 2011;29:468-71.

12. Naghshineh S, Hafler JP, Miller AR, et al. Formal art observation training improves medical students' visual diagnostic skills. J Gen Intern Med 2008;23:991-7.

13. Ousager J, Johannessen H. Humanities in undergraduate medical education: a literature review. Acad Med 2010;85:988-98.

14. Perry M, Maffulli N, Willson S, et al. The effectiveness of arts-based interventions in medical education: a literature review. Med Educ 2011;45:141-8.

15. Smyth JM, Nazarian D, Arigo D. Expressive writing in the clinical context. In: Vingerhoets A, Nyclícek I, Denollet J. Emotion regulation. New York: Springer; 2008. pp 215-233.

16. Meulenberg F. The hidden delight of psoriasis. BMJ 1997;315:1709-11.

17. Bolton G. Medicine and literature: writing and reading. J Eval Clin Pract 2005;11:1719.

18. Kaptein AA, Koopman JJE, Weinman JA, et al. Why, why did you have me treated? The psychotic experience in a literary narrative. Med Human 2011;37:123-6.

19. van Haaren MAC, Lawrence M, Goossens PH, et al. Pirandello's analogy: a source for a better understanding of the social impact of stroke. Eur Neurol 2012;67:92-7.

20. Briët M, Haan J, Kaptein AA. Hermann Hesse and L.: two narratives of sciatica. Clin Neurol Neurosurg 2012;114:9-11.

21. Das T, Kaptein AA, Haan J. The turbid crystal ball: life plans affected by multiple sclerosis: Literature and patient compared. Int Mult Scler J 2011;17:86-9. 